that the so-called splenial element is simply an extension of this. He also states that Meckel's cartilage becomes ossified and incorporated only with that part of the lower jaw which is below and inside the mesial and lateral incisor teeth. Accessory cartilaginous nuclei appear for the condylar and coronoid processes, but not, in man, for the angle. Professor R. W. Reid, the President of the society, contributes some Notes on a Mesial Sagittal Section of a Female Subject. In the section the spinal cord is compressed antero-posteriorly and laterally by a mass of gliomatous tissue which extends throughout the whole length of the spinal canal, is attached to the pia mater, and is invested by the dura mater. Professor Reid suggests that this may be an attempt at duplication of the cord but remarks that it also resembles certain cases which are described as diffuse sarcoma of the pia mater. The Proceedings contain a large amount of anthropological material. Papers are contributed by Mr. D. Horn, B.A., of Queensland on the People of the New Hebrides; by Mr. F.S. Maxwell of Sierra Leone on Hausaland and its Inhabitants; by Mr. George Moir, M.R.C.V.S., on the Natives of the Malay Peninsula; and by Captain A. W. Cook Young, I.M.S., on Tibet. In an interesting description of Four Short Cists from Aberdeenshire Dr. Low remarks that they furnish evidence of burial by inhumation as well as by incineration, the former being the earlier practice. $\mathrm{He}$ also corroborates Dr. T. H. Bryce's view that the beaker class of sepulchral urn, which is the oldest Bronze Age ceramic, is associated with a specific cranial type. We commend a paper by Mr. F. G. Parsons on the Anatomical Fducation of the Medical Student to the attention of all teachers of anatomy.

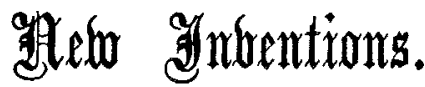

\section{MOUSTACHE CLIPS FOR LARYNGOSCOPY.}

A PAIR of small spring forceps, such as are sold for the purpose of raising the ends of the moustache, are very useful for temporarily keeping up an overhanging moustache during an examination of the pharynx, larynx, or naso-pharynx. They must be applied horizontally, just on either side of the median line, with the fluted blade below and the handles

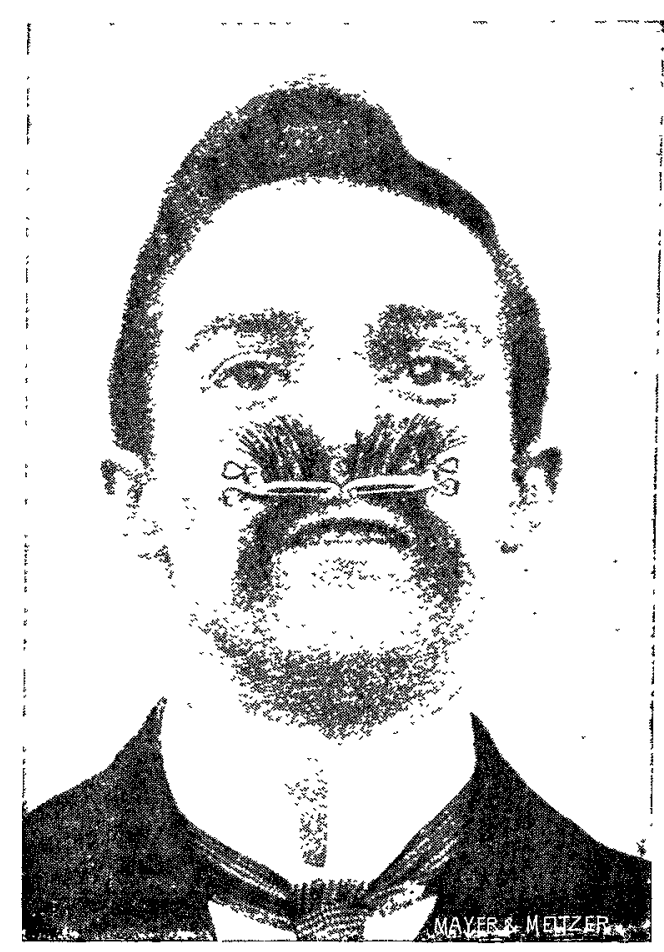

directed outwards as shown in the accompanying figure. They may be obtained of Messrs. Mayer and Meltzer, 71, Great Portland-street, London, W.

Brook-street, W.

E. CRhasswell Baber.

\section{IMPROVED MOUTH GAG.}

WHILE doing operations on the mouth I have been struck by the inadequacy of the gags in use. All that $I$ have seen are liable to slip into the mouth, particularly if there are teeth in the upper jaw and corresponding vacancies in the lower and vice versâ. To obviate this I have had a gag made which, as shown in the illustration, has two wide toothplates which fit firmly over either teeth or gum, as the case

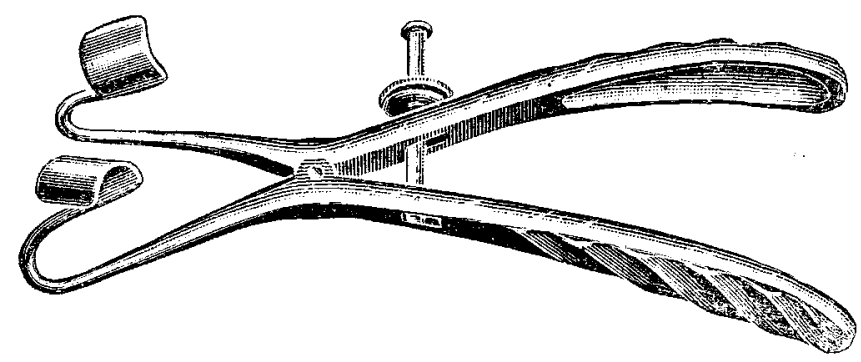

may be, and when fixed in position by the screw it is, as far as my experience goes, impossible for it to slip into the mouth or even to move. The gag, which I have been using for nearly 18 months, was made for me by Messrs. White and Wright, 93, Renshaw-street, Liverpool. The plates measure $1 \frac{1}{4}$ inches by $\frac{3}{4}$ inch and are covered with rubber.

H. LYLE, M.R.O.S. Eng.,

Senior Surgeon to the Cancer and Skin Hospital, Liverpool.

\section{THE USE OF ALCOHOLIC BEVERAGES.}

WE have received the following document for publication in THE LANCET. As an expression of scientific opinion it deserves to be considered carefully by medical practitioners. The signatories are well-known members of the profession, and the importance of the questions involved, alike from the medical and the social point of view, can hardly be overestimated.

"In view of the statements frequently made as to present medical opinion regarding alcohol and alcoholic beverages, we, the undersigned, think it desirable to issue the following short statement on the subject-a statement which we believe represents the opinions of the leading clinical teachers as well as of the great majority of medical practitioners.

" Recognising that, in prescribing alcohol, the requirements of the individual must be the governing rule, we are convinced of the correctness of the opinion so long and generally held, that in disease alcohol is a rapid and trustworthy restorative. In many cases it may be truly described as life-preserving, owing to its power to sustain cardiac and nervous energy, while protecting the wasting nitrogenous tissues.

"As an article of diet we hold that the universal belief of civilised mankind that the moderate use of alcoholic beverages is, for adults, usually beneficial, is amply justified.

"We deplore the evils arising from the abuse of alcoholic beverages. But it is obvious that there is nothing, however beneficial, which does not by excess become injurious."

T. MCCall Anderson, M.D.,

Regius Professor of Medicine, University of Glasgow. ALFRED G. BARRS.

WILLIAM H. BENNETT, K.C.V.O., F.R.C.S.

JAMES CRIChTON-Browne.

W. E. Drxon

Dyce DUCK worth, M.D., LL D.

Thomas R. Fraser, M.D., F.R.S.

T. R. GLYNN.

W. R. Gowers, M.D., F.R S.

W. D. Halliburton, M.D., LL.D., F.R.C.P., F.R S.,

Professor of Physiology, King's College, London.

JONATHAN HUTOHINSON.

Robert HuTChISON.

EDMUND OWEN, LL.D., F.R.C.S.

P. H. Pye-SMITH.

FreD. T. RoberTs, M.D., B.Sc., F.R.C.P.

EdgCOMBe VenNiNG, F.R.C.S. 